\title{
Poetic License: Using Documentary Poetry to Teach International Law Students Paraphrase Skills
}

\author{
Robin Nilon, PhD \\ Assistant Professor of Law, Beasley School of Law \\ Temple University
}

\begin{abstract}
In this article, I show how the study of the poems of Charles Reznikoff - a $20^{\text {th }}$ century American lawyer - helps teach the critical art of paraphrase to International law students, lawyers from The Temple's LLM Program. Scholars have acknowledged the difficulty of teaching paraphrase to students from civil law countries, acknowledging that it too often results in patchwriting or mere recitation, drained of any text-based policy analysis. Drawing on the fields of ESL, Composition, and Legal Writing, I show how the study of the poetry helps my student learn US-style legal writing. We use the poetry of Reznikoff, who, during the $20^{\text {th }}$ century, wrote poems about reported cases in which race played a dominant role. The students summarize Reznikoff's poems into prose form and reported cases into poetry. Moving from one genre to another enhances the students' paraphrase skills, which they then apply to a modern search and seizure problem raising the issue of racial profiling. The students now demonstrate improved paraphrase skills and are more familiar with policy analysis - skills that will greatly enhance their ability to practice law. Students in the humanities, sciences, and social sciences - any field that values critical thinking and writing - will also benefit learning these skills.
\end{abstract}

"The Economy of presentation in this writing is a reassertion of faith that the combined letters - the words - are absolute symbols for objects, states, acts, interrelations, thoughts about them. If not, why use words?" (Zukofsky, 1931, p. 285)

Teaching students to write clearly and effectively can be quite daunting. A culture that values 280 word "tweets" does not lend itself easily to more extended prose efforts. Yet, writing remains a valuable skill in certain professions, especially in law, where attorneys must compose briefs, memoranda, and motions. This kind of "adversarial" writing largely reflects counsel's ability to sort out facts and analyses in a manner most favorable to the client. This means adversarial writing - like all persuasive writing - turns on counsel's ability to paraphrase. Yet, understanding "paraphrase" as a concept, and actualizing that concept, are among the most difficult of prose writing tasks. After much trial and ...adversarial writing - like all persuasive writing - turns on counsel's ability to paraphrase. Yet, understanding "paraphrase" as a concept, and actualizing that concept, are among the most difficult of prose writing tasks. error, I have determined that students can use the reading and writing of poetry to help them improve their prose, especially in the area of paraphrase. In this essay, I discuss how the poetry of Charles Reznikoff (a twentieth Century American lawyer) can help students better grasp the concept of persuasive paraphrase. 


\section{The Importance of Paraphrase}

Legal writing is often adversarial. The writer trying to persuade a judge or a panel of judges is usually representing one side of a legal dispute or another: in civil cases the client is either the plaintiff or the defendant; in criminal cases, either the "state" or "government" (i.e., the prosecuting authority) or the person charged with a crime (also called the defendant). In advocating for a client, each lawyer is obligated to state the facts and the law most favorably to the client, taking care not to misstate or misrepresent. The result is a written version of putting one's best foot forward.

For instance, in describing the facts of a traffic accident, a neutral party might write that several people saw an SUV cruising briskly along with other vehicles on an urban avenue strike a pedestrian trying to cross the avenue. Describing the same event, counsel for the pedestrian (the plaintiff) would likely emphasize that several witnesses saw the SUV travelling at high speed when it struck the plaintiff. Counsel for the driver (the defendant) would likely emphasize that those same witnesses said that the SUV was travelling at the same speed as all the other vehicles.

Both lawyers are describing the same incident but emphasizing different facts and necessarily using different language; they are paraphrasing.

To learn effective written American-style legal advocacy, law students must learn this critical skill of paraphrase.

\section{The Elusive Art of Paraphrase}

I teach legal writing to students enrolled at a Philadelphia law school. These students hail from all over the world. Most return to practice in their home countries, where an American degree can be valuable. Others obtain the LLM degree as a means of qualifying to practice law in the United States.

Learning American legal idiom can be demanding for all students, especially for those who speak English as a second language. Learning how to use that idiom to paraphrase can be especially demanding. Despite my best efforts to teach good paraphrase practices, initial efforts often produce "patchwriting" - a form of paraphrase practiced by students with less developed reading skills - that leads to charges of plagiarism (Howard, 1995; Howard, 1999). Legal writing texts and handbooks object to patchwriting, but scholars increasingly argue that it might be a necessary stage in gaining professional writing skills (Howard, 1999). Although I accept that patchwriting may be a "necessary stage" for some students, I argue here that legal writing teachers - and, indeed, all writing teachers -- might incorporate a different genre, in this case poetry, into their courses to give students opportunities to replace re-hashed ideas with paraphrase that reflects full immersion in the source.

Foreign law students, particularly those from civil law countries (including most of Europe, China, and South America) are prone to patchwriting because, at American law schools, they are usually required to read, analyze, and summarize legal documents more complex and policy-laden than what they are used to. Further, instructing students to use synonyms and alternative syntax often leads to diminished understanding of the source itself, and so is of limited use. Fields like English for Academic Purposes, English for Specific Purposes, and English for Legal Purposes are 
helpful here. For example, in a recent dissertation, Esain (2015) describes difficulties in learning paraphrase. Citing to Wette's research, Esain notes,

When they [students] had to discuss the tasks that they had carried out, most of them agreed on paraphrasing being the most demanding one. The most frequent challenges reported by students were: 1) keeping in mind that a paraphrase should be the result of working on a certain idea, 2) understanding the meaning of the source so as to stay faithful to it, and 3) the high English proficiency level required to accomplish an accurate paraphrase. (Wette, 2015, as cited in Esain, 2015, p. 158)

Esain also draws on linguists who stress teaching students to recognize "reporting" verbs - verbs having different connotations (some denotative, some evaluative) - as a kind of direct teaching for helping students improve paraphrasing and avoid plagiarizing (Thompson \& Yuying, 1991).

I certainly agree with prioritizing paraphrase development as a primary skill for writing students. My method of implementing that priority is drawn from composition theory and the dual goals of "knowledge telling" - presenting appropriate text material, and "knowledge transforming" - developing source material into a larger piece of writing, where the writer uses source text material more substantively as a means to develop a larger theme or argument (Bereiter \& Scardamalia, 1987). This method may use techniques such as "text interviews" and "talk-aloud protocols." Nilon (2006) states, "By reading a case in a "Talk-aloud protocol, the students will determine whether he can analyze. As a basic composition skill, the talk-aloud protocol is invaluable for working through any difficult task" (p. 34).

\section{Legal Pedagogy and Literature}

Using literature (and in my case poetry) as a springboard for teaching legal writing, seminar papers, and doctrinal courses is a method well established in the legal pedagogy literature. The "law and literature" movement arguably began in 1973 with the publication of James Boyd White's seminal work The Legal Imagination: Studies in the Nature of Legal Thought and Expression. (White, 1973). Through the 1980's, the movement grew and was gradually accepted as legitimate within legal academe. It continues to proliferate with district strands and offshoots. Skeel (2009) summarizes the first strand as "law as literature" or, as he says "with a bit more bombast, the 'hermeneutical approach'." "Like White," says Skeel "scholars writing in this mode use the resources of literary criticism to examine statutes, judicial opinions, and other legal writings" (p. 926).

Skeel describes the second and third strands and cites the work of Robin West, and Martha Nussbaum, writers who highlight work that, quoting Nussbaum, "invites the readers to put themselves in the place of people of many kinds and to take on their experience" (Skeel, 2009, p. 927). This "empathetic" view leads to the third strand, "law and narrative" or "legal storytelling," practices by scholars such as Derrick Bell. This strand is associated with critical race and feminist theories. Law and storytelling "substituted literary prose for the discursive analysis of traditional legal scholarship" (Skeel, 2009, p. 928). 
I hesitate to situate my approach to teaching lawyering skills within any strand of law and literature but come closest perhaps to the work of "applied legal storytelling" as practiced by some legal writing instructors. Robbins draws the preliminary conclusion about the connection between Law and Literature and Applied Legal Storytelling: the two forms of legal dialogue can exist in parallel or can exist in overlap and all that really matters is that the applied aspects of legal writing storytelling are used by lawyers and judges, taught to future lawyers, and discussed by people who care about everyday lawyering. (Robbins, 2008, p. 11)

\section{The Legal Poetry of Charles Reznikoff}

Among the definitions of poetry is this one from the Oxford English Dictionary: "The expression or embodiment of beautiful elevated thought, imagination, or feeling, in language adapted to stir the imagination and emotions, both immediately and through the harmonic suggestions latent or implied by the words and connections of words actually used..." (Poem, 2020). For present purposes, poetry may be described as a most powerful form of paraphrase, by which the essence of human experience may be captured through the use of language. The human experiences American "objectivist" Charles Reznikoff sought to capture through the language of poetry were disputes. A lawyer by training, Reznikoff published Testimony, a book of poems addressing race and the American criminal justice system during the late $19^{\text {th }}$ and early $20^{\text {th }}$ centuries. Reznikoff based his poems on actual written court decisions. A more contrastive example of paraphrase - poetry vs. legal prose - is difficult to imagine.

\section{Use of Reznikoff's Poetry to Help Students Learn Paraphrase}

I argue that to learn effective paraphrasing, students must first create a temporary conceptual structure - a "scaffold" - of reading and writing tasks using both case materials and alternatives to case materials: in this case documentary poetry based on court cases. The "scaffold" comprises 1) reading five Supreme and Circuit Court decisions addressing when police, consistent with the Constitution's $4^{\text {th }}$ Amendment, may permissibly "stop and frisk" a person suspected of committing a crime; 2) extensive discussion of the policy implications of these decisions, especially the role that race may play in police action; 3) careful review of U.S. v. Thomas Smith, a criminal procedure problem raising issues related to the $4^{\text {th }}$ Amendment and racial profiling; 4) brief written assignments, in which each student, having been assigned the role of prosecutor or defense counsel, must analyze the facts of Smith to favor her client; 5) written legal analysis of Smith, reflecting the holding in each appellate decision as it is assigned; and 6) oral argument of Smith as either a prosecutor or defense counsel.

All law students studying U.S. law learn to recognize tensions between the U.S. legal system and individual liberties against the background of race. International law students, however, may benefit particularly in navigating contested cultural values when reading and writing prose and poetic alternatives to judicial opinions. Spanbauer 
and Lewinbuk (2009), for example, note how Martin Luther King's "Letter from Birmingham Jail" can be contrasted to the judicial opinion Walker v. City of Birmingham (1967) to demonstrate "a stark example of the judicial opinion which frequents tells a very small part of the story of the event and impact on the litigants" (p. 249-50).

In my model, as the students climb this scaffold, they review and discuss Reznikoff's poems and the written court decisions on which the poems are based. Throughout, students complete exercises in which Reznikoff's poems are seen alongside the case reports on which the poems are based. The students address what language Reznikoff has removed in his factual description, what language remains, and why the poet made the changes he did. I also ask students after reviewing other case reports and Reznikoff's related poems to convert Reznikoff's poems into prose narratives from the point of view of the defense and the prosecution.

Testimony is an unusually apt model for my students because of its hybrid approach to U.S. social history from the $19^{\text {th }}$ century through the post-War I period. Testimony, then, can be seen as a kind of masterclass, showing the ways in which witness's testimony and the apparatus or frame of jurisprudence glance off each other, in effect producing meta-judgments and rulings. The genius of Reznikoff's poetry is its "negative capability" to resist any absolute reading that purports to be the culmination of a process (Keats, 1818).

Using Reznikoff's poetry as a guide, we may help students understand the ambiguity at the heart of adversarial writing. By acting as "readers" of historical cases as translated into "facts" by Reznikoff, my students also learn to 1) develop tools of concision; 2) pay closer attention to the cultural construction of meaning inherent in any record of the facts, especially with respect to race in the United States; 3) recognize that good fact writing walks the fine line between persuasion and prevarication. Because the Smith problem is the focus of the student assignments, I will set it out here in some detail.

\section{Teaching Paraphrase - The Thomas Smith Problem}

Each student - designated as a prosecutor or defense attorney - will write a legal memorandum in which they adapt the facts of a "stop and frisk" problem arising at the intersection of race and law. Typical is Philadelphia's stop and frisk policy, derived from Chief Justice Warren's opinion in Terry v. Ohio (1968). There, the Supreme Court held that, for their own safety, police could, on less than probably cause, pat down, ("stop and frisk") an individual whose behavior is "suspicious." The decision has spawned a wealth of case law and scholarship that my students are required to read: California v. Hodari (1991); Florida v. J.L. (2000); Illinois v. Wardlow (2000); Terry v. Ohio (1968); U.S. v. Navedo (2012).

In using a Philadelphia-based federal case, I try to preserve the "real world" setting. I have adapted the judge-found facts to enhance their ambiguity and help ensure that students will interpret events, not just recite them. The problem is rife with policy issues: racial profiling, the balance between individual liberties and law 
enforcement, and always shifting Fourth Amendment concerns. It is this balance that the students must strike as they take on their roles as prosecutors and defenders.

Like Reznikoff, students learn to recognize tensions between the U.S. legal system and individual liberties against the background of race. Before writing anything, however, students must read $4^{\text {th }}$ Amendment decisions mentioned above all of which address either in the majority or dissenting opinions the problems of racial profiling and the Constitution. Students were then given the judge-found facts of the U.S. v. Smith (2015):

At 9:30 on the Evening of August 1, 2017 Philadelphia Officer George Henson and his partner, Officer Eric Parry - both in bull police uniform - were patrolling a high-crime area in North Philadelphia in their marked police vehicle. They saw a group of males - Defendant, who is African-American, and his three friends, who are Caucasian - gathered outside Norm's Bar near the 1910 block of Cecil B. Moore Avenue. The police had received numerous complaints of drug and gun crimes occurring outside the bar. Accordingly, the officers ordered the group to disperse.

Defendant's three friends immediately ran in different directions. One appeared to be holding something dark in his hand. The officers did not follow any of the three. Rather, the officers drove off. Some ten minutes later, the officers returned and saw that Defendant was standing alone in front of the bar. The officers stopped and got out of their vehicle. As they did so, Defendant began to run down Cecil B. Moore Avenue. Officer Henson, who was within 10 feet of Defendant, could see that he was holding something in his waistband with both hands. Believing that Defendant - consistent with the complaints received of gun and drug crimes -- was carrying a gun or drugs in his waistband, Officer Henson ran after Defendant. He chased Defendant for several blocks, remaining within 10 feet of him and never losing sight of him throughout. Throughout the chase, Officer Henson shouted, "Halt; police."

Officer Parry pursued Defendant in his marked vehicle. After running for several blocks, Defendant hurdled a ten-foot fence. Officer Henson could see that as Defendant landed, he turned and said, "Ok, you got me," and discarded a large black handgun. Officer Henson recovered the gun - a 9mm semi-automatic pistol - and Officer Parry then drove up to the Defendant and arrested him.

Students must then, in their own words, summarize the facts of U.S. v. Smith to favor the prosecution or the defense.

\section{Initial Resistance to Paraphrase}

Most students offer "summaries" taken nearly verbatim from Smith itself, regardless of whether they were writing for the prosecution or the defense. Typical was their use of identical words and phrases: "Officer Parry pursued Defendant in his marked vehicle. After running for several blocks, Defendant hurdled a ten-foot fence." 
To a degree this is understandable - it is difficult to replace a word like "hurdle" using an English/foreign language dictionary. My greater concern, however, was their apparent inability even to recognize the inconsistent police behavior in failing to follow the white suspect "holding something dark in his hand." As often as not, students omitted important facts, thus demonstrating their belief that the point of paraphrase was to use only the facts that would help their client and ignore those facts that hurt. One typical example: "The police ordered the four persons to disperse. Three, who are Caucasian, immediately run away. The police then drove off." This prosecutor failed to note that Thomas Smith is African-American, nor does he mention that the police see "something dark" in the white suspect's hand. This student defender sought to improve on the judicially found facts by making up a few of his own: "Thomas Smith simply did not recognize the men as police officers. He ran before he thought they could rob him." Another student writing for the defense drew conclusions in the effort to be persuasive: "That police did not pursue white people is racial discrimination." These students obviously had not yet grasped the concept of effective paraphrase, but given the challenges presented to them, immediate results were hardly expected.

I next tried to help the students understand, as did Reznikoff, the kind of "collective witness" that might be found in the facts of a reported case. After several exercises using Reznikoff's poetry, the students returned to the facts of Thomas Smith. I have set out those exercises in some detail.

\section{Morgan v. Lamb - Description}

Reznikoff based his poem "Railroads" on Morgan v. Lamb (1915), a decision of the Georgia Court of Appeals. The African-American plaintiff, Mr. Morgan, sued a rural Georgia railroad for his son's wrongful death. A white witness testified that the deceased had been thrown from the moving train by the white conductor and porter. The son's body was later found, his head "broken in and his brains knocked out." Several white trial witnesses contradicted the first witness' version, suggesting that the decedent had never been on the train.

The trial court overturned the jury's $\$ 100$ verdict for the plaintiff and retried the case. After the second jury returned a \$5,000 verdict for the plaintiff, the trial court again granted a new trial, and Mr. Morgan appealed. In a wordy, repetitive opinion which the students read - the Court of Appeals upheld the trial court's ruling, closely dissecting the evidence and concluding that the plaintiff's evidence was "weak and unsatisfactory."

This is how Reznikoff described the case in his poem (also assigned to the students):

\section{"Railroads"}

A young black, sixteen years of age earned a dollar and a half a day, and gave almost all of it to his father but kept the rest to spend on himself, with which to make his cigarettes. The train would stop for a while at the flag station and he went into the car for colored people where the "news butch" kept the newspapers, candy, tobacco, and whatever else was sold on the train and the young black bought what he wanted, and stood there talking to the "news 
butch" until the train was about to start and then he was walking to the platform to get off.

Just then the conductor and the porter, about to enter the car for white passengers, saw him and hurried up to him - train was running pretty fast shoved him out the door and threw him off the train.

“That damned n\#\#\#\# didn't mind hitting the cross-ties," said the conductor, and he and the porter turned back, and the porter laughed. The young black's body lay near the tracks, his head one or two feet towards the ditch: the head badly bruised of the forehead and the skull broken.

One of the passengers in the car for whites saw what had happened, but he was advised by his friends that the less he had to say about it the better.

My students first consider why this was a civil trial - why the conductor and the porter were not charged criminally. Students thus learn that in the early $20^{\text {th }}$ century, there was little possibility that a white citizen of Georgia would be charged with murdering a black man.

I then asked the students to write their own poetic versions of "Railroads." I urge them not to repeat Reznikoff's words, but to use their own words. They were, thus, compelled to paraphrase. The results were surprisingly good.

One student addressed the decision of the white passenger to say nothing about the murder he had just witnessed. "In the car for whites, People were eating, chatting, focusing on their own things. One of the passengers saw what had happened. Anxiety made him uncomfortable. He looked around, but finally did not say a thing." Another student chose to paraphrase with rhyming verse:

It is never without a sorrow, When a man will not see the morrow,

To blame someone without proper evidence however, Now that is never clever,

How has the one witness claim to have seen, Something that never have been.

There was more here than met the eye. Unlike Reznikoff, this student employed sarcasm to express his skepticism of the events accepted by the trial court. Similarly, this student sought to paraphrase through rhyme:

A railroad that sees thousands pass every day, Sees a man pass away

As it has so many times before, And one race wants to make it something more

Once again, the student sought to be emphatic, explicitly attributing the death to race.

\section{Prose Paraphrase Efforts}

Students were then asked to "Compare the facts as found in Morgan v. Lamb with the facts that Reznikoff included in his poem 'Railroads'." They must "focus on 
style, accuracy, what is included, what is missing, or anything else that contributes to your understanding of each document."

One student's observations were telling:

There are many differences between the court report and the poem. In the poem we have a kind 16 years old kid. The Morgan case ignored the victim. Secondly, the poem has the victim legally on the train with details of what he did. None of this was in the case report. The cases' mention of the body is not descriptive. The poem's description is.

By making these factual distinctions, this student has begun to lay the foundation of paraphrase.

The students must set out the facts from the standpoint of the defendant's and plaintiff's counsel. In these roles, the students understood the need for emphasizing some facts and deemphasizing others. For instance, as plaintiff's counsel, one student offered the following:

Sixteen-year-old Ira Morgan made little money which he used to support his family.

On July 26, 1914 got on a train in a car for colored people. He wanted to buy something from the "news butch." Morgan then stood in the colored car with the "new butch."

The train conductor went to Morgan in the colored car. The conductor said "That damn negro don't mind hitting the cross-ties!" They threw Morgan off the train onto the tracks, where they found his broken body.

Assuming the role of defendant's counsel, another student sought to criticize the poet's emphasis on unfavorable facts.

The poem is not fair or accurate. The poet says facts that make the boy innocent and dutiful. The poet ignores the testimony of the three witnesses in favor of a single witness. How can this be accurate? Was the boy trying to steal his ride? Accidentally did he fall off the train? The poem exaggerates the conductor's wickedness to make him look guilt. Can a single witness really see everything that happened?

This example is significant because the language is so overblown. The student used his own voice because he was trying to persuade the reader and so sought to correct what he believed to be Reznikoff's unfair treatment of the facts. Another student offered a similar complaint about Reznikoff's lack of "objectivity:"

The poem makes an emotional appeal. The author leans on facts that make the boy look good. He gives money to his father. This made him more than just the victim. But Reznikoff is not objective. How does he know what the conductor said or a look on his face? The court opinion is objective and more complete, not the poet.

The student is making Reznikoff's point precisely, and in doing so is defining a method of paraphrase. As an "objectivist" poet, Reznikoff says: 
I see something that moves me - if I've portrayed the object well - somebody will come along and also be moved, and somebody else will come along and say, "what the devil is this this?" And maybe they're both right. But what I've written here will perhaps answer your question more directly. By the term "objectivist" I suppose a writer may be meant who does not write directly about his feelings but about what he sees and hears; who is restricted almost to the testimony of a witness in a court of law; and who expressed his feelings indirectly by the selection of his subject-matter and, if he writes in verse, but its music. (Dembo \& Reznikoff, 1969, p. 194)

It is the music that the students began to hear.

Finally, I asked students to explain whether the poem "Railroads" or the reported facts of Morgan v. Lamb better persuade the reader. One student offers the following:

Railroads and Morgan v. Lamb are persuasive, but in different ways. The poet describes tragedy in short moving phrases. The Judge describes the death of the boy logically with fewer details about how the boy died. The judge is more objective, concentrating on important facts, not details like how poor the boy is.

It thus appears that the students have developed a more sophisticated appreciation of how a story can be told from different perspectives.

\section{Follow-up Assignments}

The exercises I have described convince me that requiring students to recite in one genre (i.e. prose) events that have initially been described in another genre (i.e. poetry) compels the use of paraphrase. Depending on the size and ability of a particular class, I asked them to do new assignments much like those that they have already done. In addition to "Railroads," Reznikoff wrote poems about other reported cases in which race played a dominant role, for example, Green v. State (1898), Ridge v. State (1911), State v. Brown (1905), State v. Flutcher (1902), State v. Powell (1904), State v. Trammel (1894), Stell v. State (1900), William v. State (2000).

Accordingly, I again asked students to restate poetic facts into prose. The repeated review of cases and poems addressing the law and race necessarily reveals the use of synonyms, related concepts, similar adversarial ideas - all of which improves the students' paraphrase skills in the act of composing (Bereiter \& Scardamalia, 1987).

Finally, the intersection of race and law in all the poems and cases imparts a vocabulary of policy - often lacking in foreign law discourse - and allows students better to understand those same issues in U.S. v. Thomas Smith.

Even more interesting results are had when students restate legal prose into poetry. Among the cases students read at the outset is Terry v. Ohio. In ruling that the Fourth Amendment allowed Cleveland Police Detective McFadden to pat down Messrs. Terry and Chilton based only on reasonable suspicion (a weaker standard than" probable cause"), the Court broke new ground. Because it seems to provoke the greatest student interest and discussion, I made another Terry the focus of student 
efforts to write poetry. I asked each student to compose a brief poem restating facts recited in Chief Justice Warren's opinion. The results were fascinating.

One student concentrated on facts mindful of those in U.S. v. Smith:

Terry, just stood on [a Cleveland] street corner, just walking up and down the same street and doing nothing he may be attracted by the goods of a store so periodically peer into a store window Just because Terry peer into the window he did nothing. The police officer found his behavior suspicious. Suspected the men of planning to rob the store.

This student did not think Terry's actions gave rise to reasonable suspicion. Another student emphasized other facts and came to the opposite conclusion.

The old detective...(on)...the street he had been assigned to patrol for more than 30 years for shoplifters and pickpockets. There are two men, Chilton and Terry back and forth along an identical route, pausing to stare in the same store window 24 times. Every time there was a conversation. Then, they were joined by a third man, who left swiftly, after another conversation.

Plainly, this student's selection of facts casts Terry's actions in an entirely different light. Indeed, another student explained that after observing Terry, "Detective McFadden...did not know why, but it just did not feel right." Accordingly, "[h]e patted down [the suspect's] coats and removed two pistols on the first two men. A robbery was nipped in the bud." Another student wrote that the Cleveland Police "[o]bserved two strangers in a high-crime area."

Significantly, the students did not ignore the case's racial aspects. One student wrote:

Two black men standing in the corner of the street, and talking with each other. One called Terry, the other is Chilton...Very far away a man in plainclothes, observed the...men...He did not know them, but he did not like them.

Another student was more emphatic:

[McFadden] questioned them just like they were already criminals, Terry and Chilton felt reluctant to answer his annoying interrogation but dared not say a definite LEAVE US ALONE

Other decisions the students read earlier in the semester also figured in their paraphrase efforts. In Illinois v. Wardlow, for instance, a closely divided Supreme Court extended Terry v. Ohio's "reasonable suspicion" standard to "unprovoked" flight from the police in "high crime neighborhoods." The majority thus upheld the police search of Sam Wardlow, who was carrying an illegal weapon. In his dissent, Justice Stevens observed that in minority communities, flight from the police to avoid racial profiling was not "unprovoked." In restating Wardlow's prose analysis into poetry, the students again recognized significant facts. Like Justice Stevens, this defender took issue with the majority's concept of provocation:

Those who aren't discrimination subject, Those who think the cops are friendly, Those people are never "provoked" to run from police. 
A student prosecutor also focused on the Court's language, albeit in different language: The high crime neighborhood the police patrol Is dangerous to one and all, When someone sees a cop and runs So the police won't find he has a gun.

At this point in the semester, students have repeatedly reviewed and restated legal prose and poetry - restating facts set out in one genre into facts set out in another. They have also been required to consider the effect of race on the law. These additional exercises suggested strongly that the students would see the facts of U.S. Thomas Smith in a different light.

\section{Return to Thomas Smith}

As I have discussed, students were initially unable to restate the facts of Smith in ways favorable to their clients. Their patchwriting and verbatim repetition of the judge found facts confirmed that paraphrase - especially in connection with social/legal policy issues - was not within their ken.

Having stated and restated the facts provided in Reznikoff's case reports and poetry, however, the students' efforts to state the Smith facts persuasively began to bear fruit. For instance, a student-prosecutor describes the Smith setting as follows: "Police saw Mr. Smith on a spot of considerable crime involving guns and drugs. Naturally, the presence of four men in this setting at night created suspicion." Another prosecutor concentrated on the actions of Smith himself: "Having failed to obey the police order to leave, Smith then left in a hurry and refused to halt." Similarly, another prosecutor also looked closely at Smith's actions: "He was holding something in his waistband, running from the cops, and disobeying their orders to halt. Isn't that suspicious?" Not to be outdone, a student-defender cast facts in a different light. "The police drove through the Temple University area at night. They think any minority in that area was probably involved in a guns or drugs." In thus learning how to emphasize facts, students are attempting to paraphrase.

The officers' failure to pursue the white suspect (surely the fact most helpful to the defense) became the focus of this student-defender's paraphrase: "Two men fled from police that night. They are both 'holding' an object. Yet, the officers let the Caucasian's pass and pursued Smith only." Faced with facts strongly suggesting racial profiling, this student-prosecutor tried to emphasize other facts: "Of the four men the cops witnessed, Smith acted the more suspicious. Unlike the others, he ran from them only when they left their patrol car looking like they would search him." Once again, by emphasizing (but not distorting) facts, this student, tried to make the best of a bad situation - often the advocate's role.

As I have discussed, before they began writing exercises, the students were assigned several judicial opinions addressing law and race. Before reading and restating the Reznikoff poems and case reports, students made virtually no mention of those decisions in their failed efforts to re-state the facts of U.S. v. Smith. After completing the Reznikoff exercises, this student-defender sought to explain her client's flight from the police as follows: "In pursuing the only black man, Mr. Smith, the police emphasized with Judge Stevens wrote in Wardlow. That in minority neighborhoods, people can run from police because they are racist." A student prosecutor emphasized 
certain facts in a way reminiscent of the majority opinion in Hodari D.: "Smith ran from the officers for no reason. As the Hodari D. Justice wrote, only the guilty run unprovoked from police."

Having initially ignored policy considerations, the students now argued policy concerns vigorously. This defender viewed the suspect actions of the police in a broader context. "That the cops failed to take any actions connected to the white suspects is a reflection of society's woes. Why should the police be free from a problem everybody else has?" Another defender was able to combine policy and paraphrase most convincingly:

High crime areas, citizen complaints, corner discussions with friends, fear of police, running from police - these are all perfectly innocent things happening in minority neighborhoods. If they are called suspicious," it is just an excuse to justify police of search all those who live in minority neighborhoods.

Students have yet to learn how to separate legally significant facts from legal arguments. Considerable law and literature scholarship suggest that the skills of persuasive fact writing can be learned given appropriate instruction in the legal writing classroom (Foley \& Robbins, 2001).

\section{Conclusion}

The students' improving paraphrase skills are encouraging, up to a point. After Reznikoff's emphasis and re-emphasis on race and the law, it is not surprising that students draw more heavily on race and policy when returning to the Smith facts. Still, however modest, their new- found ability to restate facts persuasively is undeniable. Moreover, scholarship suggests that language ease and familiarity as a concomitant of paraphrase are all transferable to writing and speech generally. Such skills would be valuable to students in myriad disciplines. Literature exists on the difference in the rhetorical structure of abstracts, in particular in the human sciences, and emphasizes the need for students to describe their activities with greater clarity and reason (Stotesbury, 2003). In a creative example of a cross-disciplinary use of method, one writer draws on Swales and Feak's 2009 model of social science abstract writing and applies it to writing in the humanities (Troutman, 2019). Troutman notes that "Abstracts provide a remarkable rich platform for teaching key academic writing practices - concision, clarity, summary, paraphrase, and selective quotation" (Troutman, 2019, p. 16). Other scholars have provided accounts of the genre of social science research articles with focus on how academic writing processes are constructed in a text (Lewin et al., 2001). Students in all these fields would thus benefit greatly from learning how to paraphrase - to restate the words, actions, results, data propounded by others.

The use of poetry to impart discipline to the thinking and writing of students in many fields is thus an idea whose time may have come. 


\section{References}

Bereiter, C., \& Scardamalia, M. (1987). The Illinois v. Wardlow 528 U.S. 119 (2000) psychology of written composition. Routledge.

Keats, J. (1818). The complete poetical works and letters of John Keats, Cambridge Edition.

California v. Hodari D. 499 U.S. 621 (1991) Houghton, Mifflin, and Company.

Dembo, L. S., \& Reznikoff, C. (1969). Lewin, B. A., Fine, J., \& Young, L. (2001).

Charles Reznikoff. Contemporary Expository discourse: A genre-based approach

literature, 10(2), 193-202. doi: to social science research texts. Continuum.

$10.2307 / 1207760$

Esain, A, E., (2015). The challenge of paraphrasing [Unpublished dissertation]. Universidad del Pais Vasco, Spain. Retrieved from

https://pdfs.semanticscholar.org/2957/b2

7a89c0f2956d4019228fa792c558bea46b.pd $\mathrm{f}$

Morgan v. Lamb 85 S.E. 592 (1915)

Nilon, R. (2006). The calculus of plagiarism: Toward a contrastive approach to teaching Chinese lawyers. South Carolina Journal of International Law and Business, 2(1), 1-48. https://scholarcommons.sc.edu/scjilb/vol 2/iss $1 / 4$

Florida v. J.L., 529 U.S. 266 (2000)

Poem. (2020). In Oxford English Dictionary.

Foley, B. J., \& Robbins, R. A. (2001). Fiction 101: A primer for lawyers on how to use fiction writing techniques to write persuasive fact sections. Rutgers Law Review 32, pp. 459-483.

https://www.lwionline.org/sites/default/f iles/2016-08/Foley.pdf

Retrieved from https://www.oed.com/

Ridge v. State 134 S.W.732 (1911)

Robbins, R. A. (2008). An Introduction to applied legal storytelling. Legal Writing, 14 (1), pp. 1-12.

Green v. State 35 S.E. (1898)

Skeel, D. A., Jr. (2009). "Some sort of chronicler I am": Narration and poetry of Howard, R. M. (1995). Plagiarism, authorship, and the academic death penalty. National Council of Teachers of English, 57, 788-807.

https://pdfs.semanticscholar.org/8cd9/53 d7a3b8de9909bb59286aa929e648fd8e09.p df

Lawrence Joseph. University of Cincinnati Law Review, 77(3), 921-939.

https://searchworks.stanford.edu/view/8 535903

Spanbauer, J., \& Lewinbuk, K. (2009). Embracing diversity through a multicultural approach to legal

Howard, R. M. (1999). Standing in the education. Charlotte L. Rev., 1. 223- 253.

shadow of giants: Plagiarists, authors, collaborators (Vol. 2). Ablex.

State v. Brown 87 S.W. 519 (1905)

State v. Flutcher 66 S.W. 429 (1902)

InSight: A Journal of Scholarly Teaching 
State v. Trammel 18 S.E. 940 (1894)

Stell v. State 58 S.W. 75 (1900)

Stotesbury, H. (2003). Evaluation in research article abstracts in the narrative and hard sciences. Journal of English for Academic Purposes, 2(4), 327-341. http://dx.doi.org/10.1016/S14751585(03)00049-3

Terry v. Ohio 392 U.S. 1 (1968)

Thompson, G., \& Yiyun, Y. (1991). Evaluation in the reporting verbs used in academic papers. Applied Linguistics, 12(4), 365-382.

https://doi.org/10.1093/applin/12.4.365

Troutman, P. (2019). Cross-disciplinary concision and clarity: Writing social science abstracts in the humanities. Prompt: A Journal of Academic Writing Assignments.

https://doi.org/10.31719/pjaw.v3i1.31

U.S. v. Navedo 694 F.3d 363, (2012)
(2015)

Walker v. City of Birmingham, 388 U.S. 307 (1967)

Wette, R. (2015). Evaluating student learning in a university-level EAP unit on writing using sources. Journal of Second Language Writing, 19(3), 158-177.

https://pdfs.semanticscholar.org/2957/b2 7a89c0f2956d4019228fa792c558bea46b.pd $\mathrm{f}$

White, J. B. (1973). The legal imagination: Studies in the nature of legal thought and expression. University of Chicago Press.

William v. State 25 S.E. 681 (2000)

Zukofsky, L. (1931). Sincerity and objectification: With special reference to the work of Charles Reznikoff. Poetry, 37, 272-285.

https://www.jstor.org/stable/20577923?se q=1\#metadata_info_tab_contents

Professor Robin Nilon received her PhD in English from Temple University in 1993 and has taught writing and English at Temple and other universities since 1985. She played a key role in reforming the Composition component of the undergraduate curriculum at Temple. In 2002, Professor Nilon began teaching legal research and writing to International LL.M. and Exchange students at Temple Law. Professor Nilon also teaches the scholarly writing process to International students. She teaches legal research and writing to students from Temple's Master of Law's Program at the Beijing campus and during their eight-week semester in Philadelphia. She is the Director of Temple Law's Writing Center for International Programs. 